\title{
Poetic Sound Picture of the World: Theoretical basis and Approaches to Practical Investigations
}

\author{
Natalia Atamanova* \\ Bryansk State University named after Academician I. G. Petrovsky, Bryansk, The Russian Federation; \\ atamanova2001@list.ru
}

\begin{abstract}
The article considers conceptual aspects of the theory of poetical sound picture of the world as one of the linguistics and culturology directions in the language study, verbalized by means of poetical sound images and represented by the multitude of the author's individualistic ideas of the sounding world, reflected in the Russian poetical idiolect; the way of conceptualizing the poetical sound space. The sound image, as one of the component elements of the literary artist's language picture, is analyzed with the examples of the precedence samples of the Russian poetry of 19th-20th centuries from the point of view of its manifestation in different spheres of poetical universe, in the light of the key lexemes of poetical idiolect.
\end{abstract}

Keywords: Poetical Idiolect, Poetical Language Personality, Sound Picture of the World, Sound Image, Sound Art Space

\section{Introduction}

A literary text, a poetical text in the first place, is contemplated in the modern linguistics as a complex sign, where the author's individual picture of the world is represented with the help of lexical and grammatical linguistic means. In this regard, the key characteristics of a poetical text are considered to be its fragmentariness, emotionality, figurativeness, mentality and conceptual structure.

As a rule, the content and association field of the literary text "reflect not only the structure and the pragmatics of the text, but also the language personality of the author and the special features of his poetical picture of the world"'. The modern linguistics and culturology understand the language personality of the literary artist as the language personality of a writer or a poet, which stands behind every literary text and is characterized not only by the degree of the command of language, but also by the choice of the linguistic means of different levels for realizing specific creative purposes. With that, the artist's exclusive role is postulated in enriching the general conceptual picture of the human world, and, as a consequence, in enhancing the treasury of the language and the culture. According to author in ${ }^{2}$, an artist "just makes the things inherent in all the people more intense and deep".

The text of the work of art, and, to be more precise, the creative activity in general, comes forth as a discourse of the author's language personality. Based on this, one can recreate all the planes of the language personality of the text creator, determined by ${ }^{3,4}$ its structural and language plane; the linguistic and cognitive one, namely, the artist's picture of the world, included in his thesaurus as a core; motivation plane, that is the plane of the language personality organization, characterizing its language behavior, its motives and goals. As a result of studying the language personality of the literary artist, the text will appear as "the moment of his creative activity, capturing all the undercurrent planes of human language activity, connection with his vision of the world, his system of ideals, value orientations, his strivings" 5 .

\footnotetext{
${ }^{*}$ Author for correspondence
} 
In the conceptual structure of the language personality phenomenon the absolute position is dedicated to the individual picture of the world, determining the specific world view of the author. The language picture of the world, in contrast to the everyday language picture of the world, represents the embodiment of an artistic world view of the poet or of the writer, or, in other words, "the image of the world, reproduced by the word" 5 . This image is formed in the framework of a special artistic picture of the world, created and expressed by means of the poetic word and possesses very vivid individualistic character, in so far as it bears the sign of the language personality's unique vision of the world. In other words, the poetic picture of the world is the "conceptual system, aesthetically meaningful, giving structure to individual creative activity in creating and interpreting the alternative poetic reality", ${ }^{6}$ distinguished by the subjective modality, emotionality, fragmentariness. At the same time the individual author's modality is contemplated as "the means of interpreting the objective reality in artistic form, revealing the personality of the writer himself"

The science of language contemplates different types of incarnating the artistic vision of the world. Among them the visual, sound, smell, touch, space, time pictures of the world are considered to be the most developed, scientifically justified and universal as regards transferring the author's perception of the world ${ }^{8}$. The idea of the sound picture of the world, being the least investigated, but, undoubtedly, the important one, is based on the multitude of hearing impressions, sound images, created in terms of hearing cognition of being 9 .

It is well known that sound is a very important share of all hearing information, and, along with color, plays a considerable part in forming the human system of the surrounding reality perception.

In modern understanding a sound is an object of several different sciences; psychology and physiology are very interested in the problems of studying it in the first place. A sound spectrum is a non-discrete continuum, formed, predominantly, by smooth alteration of the sound wave length. The attribute, by means of which the perceived sounds are differentiated one from another and are placed within the spectrum, is determined by the acoustic features of the sound, where such features as tone and noise are identified. The important characteristics of a sound as a physical value are timbre, pitch and strength. Physiology and psychology contemplate sound from the position of its physical (acoustical) and physiological (articulation) characteristics.

As the new branches of the language science develop, such linguistic sciences as, in particular, phonology, lexicology, psycholinguistics, phonosemantics, get involved in studying the specifics of sound as an object of hearing perception. At this stage of the language development several aspects can be identified, the basis of which is formed by studying the sound as an object of linguistics: Investigating sound from the aspect of the correlation between phonation and sense (phonological aspect); contemplating sound in the light of identifying the lexical and semantic clusters or semantic fields (lexical and semantic aspect); sound analysis in terms of the literary artist's creative activity, of the peculiar features of his world view and his personal characteristics, helping represent the author's individual poetic sound picture of the world.

The specified aspects of studying sound make it possible to consider the very notion of sound from different positions. In the lexicographical aspect the idea of sound is usually narrowed down to two moments: first, the sounds are understood as "minimal articulate elements of speech with intrinsic physical attributes" ${ }^{10}$ or "a simplest constituent of an articulated word ${ }^{11}$, i.e., the phonetic side of a sound; second, a sound expresses "the thing that is heard, that is perceived by the ear, effected by the mechanical vibrations ${ }^{10}$, i.e., by any sound in general, identified in the language by means of a word and possessing the notional form, the meaning.

\section{Literature Review}

As we can see, in the modern linguistic science the very question of phonation is theoretically ambiguous and is, therefore, in need of more thorough and complex investigation. On the one hand, a sound, as a unit of the phonetic system, possesses the definite phonetic meaning of its own, the value attributes, defining the connotative coloring of a word, and is in this respect an object of study of the specific branch of linguistics, phonosemantics, within the framework of which the issue of artistic and descriptive features of sounds in poetic text are studied ${ }^{12}$, the problems of semantics sound arrangement in the text and the sound pattern means are investigated ${ }^{13-15}$, the theory of color-sound correlation and the perceptive synesthesia is considered ${ }^{16-18}$, sound stylistics, sound symbolism are contemplated ${ }^{19,20}$, etc. 
On the other hand, the sound is understood as a kind of a sounding image, or sound image, generated out of a range of the sound designating words, used by the authors in the contexts of their poetic creations and serving the purpose of characterizing different theme aspects, particularly, for describing the environment, the spiritual state of a subject, the poet's creative reaction. In so far as in the context of a poetic creation the sound images become even more effective, meaningful and symbolic, they are of the greatest interest for a linguistics scientist. This question, however, as the scientific investigations of the latest years testify, is hardly studied by the modern linguistics ${ }^{2}$. The idea of a sound image is only presented either from the view point of investigating the lexical and semantic field "Sound"23-26 or from the view point of the grammatical aspect, i.e., the study of lexical units of a definite grammatical category (nouns-, adjectives-, adverbs-sound images, the verbs of sound), their morphological structure, word-formation capacity, syntagmatic potential capacity ${ }^{27-30}$.

The polysemic nature of the idea of sound, reflecting the problem of unity of the designating and the designated, makes it possible to introduce the concrete definition, meaningful for solving the problem under investigation. Expressing the lexical aspect of the idea, the sound is understood as a system of sounding images, or sound images, the principal lexical elements of the "sound" poetic system, playing an important part in creating the artistic image, in revealing the author's specific techniques and ways of poetic vision. The sound designations in the poetic language possess vividly expressed nationalcultural and subjective-modal specific features, and are the meaningful elements for constructing a fragment of the artistic picture of the world in the concrete poetic idiolect.

In the modern linguistic investigations the sound image is understood as "internal form of the artistic speech, the result of all aesthetically meaningful sound repetitions, expression of unity, principle tone value of the work of art interacting with the concept and content information of the artistic whole" 31 . The sound image is an "acoustic invariant, associated with definite idea (meaning)"32, "an artistic image which is seamlessly interwoven into the image tissue of the complete work of art and which possesses philosophical, aesthetical, religious, ethical, mythological content, stipulated by artist's spiritual coordinate system"33. Undoubtedly, the poetical sound images are exceptionally charged in connotative aspect, as they appear to be the bearers of subjective evaluating information, motivated by the multitude of the author's world outlook knowledge, existing in his consciousness. In the semantics of the poetical sound image a subjective factor comes forth to the front, which cannot be separated from national and cultural specific features of the language awareness in the wide sense.

Studying the semantics of the sound images crucial for a certain poetic system helps creating the sound picture of the world and its lexical and semantic representation in the context of poetic activity. Poetic sound picture of the world is verbalized by means of sound images, the multitude of which is used to characterize such phenomenon as sound space, represents the author's individual set of ideas about the sounding world, reflected in Russian poetical idiolect, the way of conceptualizing the sound space. In the poetical sound picture of the world the author's world view knowledge system is reconstructed, which exists in poetic consciousness and is reflected in the poetic creative works. With the help of the sound image the world can be described in the same way in which it appeared before the poet.

Undoubtedly, in forming the artistic picture of the world the lexis constituting the individual poet's vocabulary plays an active part, which testifies to realizing the sound picture of the world in lexicographical aspect. Due to this fact this study encompasses the issue, relevant for the modern linguistic science, of presenting the individual poet's lexicon, "as the compilation open for review" ${ }^{34}$, the author's vocabularies, which, according to Andrey Bely, are "keys to the mysteries of the poets' spirits", and which can become the "measuring lot" of their self-consciousness ${ }^{35}$. Analysis of sound images in poetical contexts will help giving the preliminary description of some aspects of the author's vocabulary, particularly, syntagmatic relations, frequency of using the sound lexemes in poems, their word forms, illustrations.

Thus, the purpose of this study is to develop the theory of the sound image, contemplating sound as one of the constituent elements of the literary artist's language picture of the world from the point of view of its manifestation in different spheres of poetical universe in the light of the poetical idiolect key lexemes, exemplified by precedent samples from Russian poetry of 19th-20th centuries, particularly, from the poetic systems of such greatest masters of the word as M. Y. Lermontov, F. I. Tyutchev, A. A. Fet, A. K. Tolstoy, Y. Baratinskiy, A. Blok, M. Tsvetayeva, A. A. Akhmatova, etc. 


\section{Methodology}

The set out goal defined a range of the scientific research methods, among which the descriptive method, the method of semantic and component analysis, the linguostylistic analysis, the structural-field method, and the elements of the statistical analysis were used.

The descriptive method involves the sound material collecting and organizing, the characteristic of its composition and structure, the distribution of the poetic speech word and sound-naming in the lexical-semantic groups with the access to the advanced level of the scientific research.

The semantic and component methods were used by us to carry out the linguistic analysis of sound lexical units in terms of their content-semantic meaning in a poetic context.

The methods of linguostylistic analysis provide a choice of different techniques for the poetic text analysis from the standpoint of the traditional and individual style of the author.

Structural-field method allows representing a classification of the research material from the point of identification of lexical-semantic fields and lexicalsemantic groups.

The method of statistical analysis intends to establish numerical characteristics and functional relationships between them, based on the continuous sampling of word and sound-naming from the poetic context, determining their frequency for a particular poetic system. Since the vocabulary of a sound is the object of different poetic systems research, the comparative method is recognized as an objective one by which we define the specific character of the sound images use in each of the poetic styles, their functional, linguistic, semantic and meaning peculiarities in relation to each other are described.

\section{Results}

In the course of the research the following techniques and methods of linguistic representation of sound images as a part of the poetic sound picture of the world were revealed:

- A sound in a poetic text becomes an important link that allows to reconstruct a set of philosophical knowledge, existing in the mind of the poet, reflected in his works. The main means of the explication of the poetic sound picture of the world is the "sound" lexical layer, a total number of word and word-naming performing a significant meaning function in the contexture of the poetic text.

- The idea of creating the sound image theory, which considers a sound as one of the constituent elements of a language picture of the artist's world, the words of Russian poetic idiolect of the 19th-20th centuries, enables to extract and formulate a common poetic "sound" model representing the idea of sounding poetic space.

- The common language sound classification based on the traditional allocation of classification principles "sound character", "sound source", "sound perception", is refined and expanded, taking into account the individuality and originality of the poetic text.

- The phenomenon of syncretism in the sound field is manifested by the example of the sound image ratio with other perceptual modes - light, color, smell.

- The main ways of sound image in the poetic context is metaphor, sound symbolism, simile, contrast, occasional words and sound-naming, sound semiotics in the traditional folk culture and the poetic text studied by the example of the bell-ringing image.

- In the semantics of the key sound images for the Russian poetic idiolect of the 19th-20th centuries specifically author's modes of the sound representation are marked.

\section{Discussion}

As the illustrative material shows, the key lexical units denoting different tonal sounding are "zvon" [ringing], "krik" [scream], "gul" [buzz], "grom" [thunder], "klich" [call], "vopl" [wail], "gam" [babel], "klik" [shout], "grokhot" [rattle], "svist" [whistle] in the poetic text. Each poet has his individual sound tone. Language sound lexical units perform nominative-illustrative, aesthetic and symbolic functions in a poetic text.

The distanced author's approach to the soundnaming selection to build a sound picture of the world leads to the following observations. F. I. Tyutchev, a poet-philosopher, a deep thinker, felt both natural and musical, harmonious beginning of the world around us, hence we can see the synthesis of harmonious, natural, thundering, symbolizing "complete consonance in nature" as a characteristic of his poetic system. The musicality, melodism, lyrical melodiousness of both F. I. Tyutchev and A. A. Fet make the basis of their lyrical systems. A. S. Pushkin gives preference to the music, melodious sound 
("zvon" [ringing], "pesnya" [song], "penie" [singing]), the lexical item "pesnya" [song] registers, according to the frequency dictionary, the maximum frequency of usage 310 times. M. Yu. Lermontov is called the poet-musician possessing a special sensitivity to the sound, a kind of "musicalisation" of the soul ("zvon" [ringing], "golos" [voice], "muzyka" [music], "pesnya" [song]), at the same time his lyrics filled with the rich pessimistic notes reflects a vivid representation of twangs ("voy" [howl], "vopl" [wail], "rev" [roar], "ston" [groan]). In the poetry by A. A. Akhmatova voices of emotions and the speech stream carrying the semantic meaning, the sounds of music and the arts are heard. In the lyrics of A. A. Blok sonic contrast of sound and silence, close and distant sounds, the sounds of the human and natural worlds are clearly observed.

In addition, sound images, as shown by the poetic context can be an important component of a more complex image, or represent the most significant image embodying ethical, aesthetic and spiritual values. For example, "plyaska s toptaniemisvistom pod govorpianykhmuzhychkov" [a dance with trample and whistles amid the talk of drunken men] is a sound component of a versatile image of the Motherland in the mature works of M. Yu. Lermontov, and the image of "pesnimateri" [the mother's songs] and "zvukovsladkogogolosa" [the sounds of the sweet voice] singing about love is the embodiment of the desired harmony, refreshing and comforting. In the poetry of $\mathrm{F}$. I. Tyutchev "gul" [buzz] performs the role of a significant sound image which is an essential feature of the night deaf time, as well as "znakomiy, vechniyzvuk" [a familiar and timeless sound], projecting an echo of the poet's love experiences. In the verses by A. A. Block the stable repeatability of the opposition "blizkiyzvuk - dalniyzvuk" [close sound - distant sound], carrying a secret and poetic ambiguity, typical for the symbolic perception of the idea of understatement, unexpected reticence is extremely important.

The thrill of a sound as one of the manifestations of life, the existence in the world of sounds allowed poets to create a harmonious picture of the sounding world, where everything is significant and symbolic, concrete and at the same time generalized. The conception of the sound reflected in the Russian poetic idiolect, allows making and formulating a common poetic "sound" model representing the idea of sounding poetic space: "sozvuchiepolnoe v prirode" [full consonance in nature] ${ }^{36}$, "vsekrugompoyot" [all around is singing] ${ }^{37}$, "tsarstvuyutzvuki" [the sounds reign $]^{38}$.
The lexical-semantic aspect of the sound image study in a poetic text involves the allocation of principles for the organization and classification of word and wordnaming. As such the principles of "sound character", "sound source" and "sound perception", which are partly based on the idea of a sound as a physical phenomenon, possessing a set of binding characteristics (e.g., intensity, longitude, pitch, and intonation) are usually singled out. The practical observations on the poetic text confirm the complexity and diversity of the sound source display, and therefore contribute to the clarification of the classification index. Based on the research of S. V. Stefanovskaya ${ }^{39}$, we distinguish a "live-sounding world" and "dead-sounding world" as a boundary of the sound source classification principles.

"Live-sounding" world includes the sounds of man as a biological being as a being who speaks and feels the sounds of a creative person ("zvuk" [sound], "krik" [scream], "voi" [howl], "vopl” [wail], "gam" [babel], "klik" [shout], "ston" [groan], "shum" [noise]; "govor" [talk], "golos" [voice], "glas" [tune], "rech" [speech], "govorit" [to speak], "skazat" [to say], "glasit" [to fable], "vozglasit" [to proclaim], "sprashivat" [to ask], "besedova" [to converse], "zvat" [to call]). Sounds of a person may be defined as primary (a laughing, crying, talking, singing person) and secondary (sounds associated with the movement in space, using a variety of objects (musical instruments, machinery, and vehicles), natural human actions ("svist" [whistling], "krik" [screaming], "stuk" [knocking], "skrip" [squeaking], etc.). The sounds of animals, birds, insects, and flora ("rykanye" [roaring], "stenanye" [groaning], "zavyt" [to start howling], "zarychat"” [to start growling], "zarevet" [to start bellowing], "layat" [to bark]; "trezvon" [chime], "krik" [scream], "gam" [babel], "svist" [whistle], "shchebetanye" [chirping], "gvalt" [rumpus], "glas" [tune], "pesn"” [song], "karknut" [to croak], "shchebetat"” [to chirp]; "piskkomara" [a mosquito whining], "golosstrekozy" [the voice of a dragonfly], "shelest" [rustle], "shorokh" [murmur], "shumet" [make noise], "shurshat" [to shuffle], "shelestet" [to rustle]) also refer to the "live-sounding world".

"Lifeless sounding world" includes the sounds of nature: the earth and water bodies ("shum" [noise], "gul" [buzz], "rev" [roar], "svist [whistle], "vizg" [shriek], "voy" [howling], "penie" [singing], "govor" [talk], "shepot" [whisper], "shumet" [make noise]), of the natural world: Fire, rain, wind, thunder, and storm ("tresk" [crackle], "zvuchat" [to sound], "pet" [to sing], 
"grokhot" [rattling], "shum" [noise], "glas" [tune], "pet" [to sing], "vyt" [to howl], "svistet" [to whistle], "raskaty" [thunder blasts], "grianut" [to break out], "gremet" [to rattle]), musical instruments ("arpha" [harp], "baraban" [drum], "buben" [tambourine], "kimval" [cymbal], "lira" [lyre], "svirel" [flute], "rozhok" [horn], "organ" [organ], "zvon" [ringing], "zavyvanie" [howling], "zalivat'sya" [to sing exuberantly], "zvuchat" [to sound], "pet" [to sing]), objects ("svistpoloz'ev" [the whistle of the slides], "shumveder" [the rattle of the buckets], "zvuktsepey" [the sound of the chains], "grompushek" [the bellow of the cannon], "peniekoles" [the singing of the wheels], "gulparokhoda" [the buzz of the steamer]), as well as multi-functional sounds accumulating the folk poetry and cultural traditions and expressing semiotic understanding ("zvonkolokol'niy" [the bell ringing], "glas Boga" [the voice of God], "peniedushi" [the singing of the soul], "otkliksud'by" [the response of the fate], "shum" [noise], "krik" [shouting], "svist" [whistle]).

Such classificatory indicators as "character of the sound" and "perception of the sound" in a poetic text do not undergo changes and are contemplated in line with traditional typology. Thus, within the microfield "character of the sound" the microclusters "sound intensity" (loud sounds - krik [scream], gromkiy [loud], gremet' [to rattle], gryanut' [to burst out], klich [call], klik [shriek], gvalt [rumpus], shoom [noise], gul (buzz, booming, clash) etc., and weak sounds - lepet [prattle], shorokh [murmur], shelest [rustle], shopot [whisper], shchebetanye [chirrup], shchebetat' [to chirp], etc.), "quantity of sound" (plangent sounds: voy [howl], vopl' [wail], ryov [roar], ston [moan], etc.; short sounds: smekh [laughter], smeyatsya [to lough]) and "pitch of sound" (svist [whistle], tresk [crackle], vizg [shriek, squeak], skrypet' [to creak], zvon [ringing], pisk [peep], etc.) are to be identified. Micro-field "perception of sound" is built in the poetic text by means of distinguishing the type of the perceived sound, by its evaluation, by the period of time, when the sounds were perceived by the poets, by the assumed source of the perceived sound, by the poet's creative response.

As the sounds themselves are diverse, so diverse are the ways of describing them in a poetic text. Along with sound symbolism, sound pattern, the most frequent of them is metaphor, with the binary metaphoric constructions being widely spread, where the phonation, intrinsic for a human, describes the sounds of birds, of the objects of nature or of inanimate objects. Among this type of metaphors one can mark genitival metaphoric constructions (glaszhavoronka [voice of the skylark], zavyvanyekolokolov [howling of bells], penyevoln [singing of waves], ropotmuki [grumble of anguish], svistpolozyev [whistle of sledge runners], etc.), verbal-nominal (ptitsybeseduyut [the birds are talking]; vodypeli [the waters were singing]; fontanlepetchet [the fountain is prattling]; klyuchgovorit [the spring-well is speaking]; buryapoyot [the windstorm is singing]; poyutderevya [the trees are singing]; rodnikshepchet [the spring-well is whispering], etc.) and the metaphors which unite an adjective and a noun into one construction (gremyashchayat'ma [rattling darkness], rumyanoyevosklitsaniye [ruddy exclamation], zvutchashchiyeluchi [sounding rays], tikhayapolumgla [silent half-light], sumraknemoy [dumb twilight], igrivoyezhurchanye [playful prattle)). In the context of the poetic activity such occasional metaphoric combinations as zvonshaleyishub [jingle of shawls and fur coats], prozvenevshiysmekh [the laughter that has rang], plyvyottserkovniyzvon [the church bell toll is swimming], zvenyashchiyetranvayi [jingling trams] ${ }^{40}$, zvuchnayatishina [resonant silence], tikhiyshoom [soft noise]), golubizveneli [the doves were jingling], svistishipenyepoyezdov [whistle and hissing of the trains] ${ }^{41}$, shorokhizelyoniye [green rustle], Paskhivetermnogozvonniy [the poly-jingling wind of Easter], zvuktvortchestva [the sound of creativity] ${ }^{42}$ can be found.

One of the means of representing a sound in a poetic text is simile. In the semantic expression of the sound perception model, built up in the lyrical system of A. A. Blok, there sequentially appears one of their types, namely, the contrast. It encompasses three planes of manifestation: opposition "sound - silence", which represents presence or absence of the sound movement; opposition "a sound which is near - a sound which is far off", symbolically equating to the idea of suddenness, of the mystery of anticipating the sound process; opposition "the sound of a human voice - the sound of nature", identifying the source of the sound emanation.

Occasional sound formations, imparting originality to the poetic text and proving the fact that the sound identifications do exist as "open-endedplurality" 43 , find their expression in the versified compositions of $\mathrm{F}$. I. Tyutchev. To the most favorable of them belong the neologisms with the initial part sladko- [sweet], which is, perhaps, due to the poet's specific perception of the melodious, ear-pleasing sounds: sladkoglasnypesni 
[sweet-voiced songs] (cf. common language sladkozvuchniy [sweet sounded]), sladkopevniygeniy [a sweet-singing genius], sladkopevnost' poeta [a sweet singing nature of the poet]. Combining the archaic features (shortened formsladkoglasny [sweet-voiced]) and the author's specific manner of word formation (almost everywhere F. I. Tyutchev creates adjectivebased constructions like sladkopevnost' [sweet singing nature], sladkoglasye [sweet voicing], sladkozvutchye [sweet sounding]), such sound notations acquire poetic metaphorical qualities. Therefore, one can grasp the finest nuances of phonation and express the emotional perception of sound simultaneously, which is a specific trait of the author's individual poetic style. Particular expressive characteristics belong to the synesthetic occasional nominations, based on the poet's customary combination of sound and light: gromkokipyashchiykubok [the loudly boiling cup], zvuchno-yasniygoloszhavoronka [resonant and clear voice of the skylark]. In Tyutchev's poetic contexts the occasional formations characterize the process of sound perception (sladkozvutchniy [sweet-voiced]), specify the concrete way of its behavior (raznogolosniy [dissonant], stozvutchniy [in a hundred of sounds]), identify the process of movement by means of actualizing the sound attributes (zvonko-begushchiy one that runs resonantly], zvonko-skatchushchiy [resonantly jumping]). The epithet stozvutchniy (of a hundred sounds), defined as "multi-sounded, multivoiced"4 ${ }^{\prime \prime}$, is chosen by F. I. Tyutchev to express a complex of heterogeneous sounds, conveying their mixture, gradation (stozvutchniystory [a hundred voiced array]; stozvutchniygul, krik, vopl', poroyugor'kiysmekh [a hundred voiced buzz, scream, wail, sometimes a bitter laughter]). By means of the occasional combinations zvonko-begushchiy [the resonantly running] and zvonkoskatchushchiy [the resonantly jumping] the dynamics of movement is being strengthened. As we can see, the use of such lexemesserves the purpose of creating special expression, emotionality of the poetic text.

The semiotics and the symbolic expression of sound are vividly realized in a special type of sound, in the image of tolling of bells, which was, from time immemorial, considered to be an inseparable part of Russian people's life, a symbol of Russian culture and domestic life, a meaningful attribute of Russian real space and time. The literary artists' perception of this people's life piece of reality is multifarious, subjective, and it represents, as a rule, a consequence of reflecting a unique world view of the creative personality and of the epoch. In the poetic language the image of toll acquires a bright symbolic standing, demonstrating general linguistic and social understanding of this phenomenon in Russian culture: mednayaburya [brasstempest], zvonmedipravoslavnoy [chime of the Orthodoxbrass] ${ }^{36}$; goolpotekhikolokol'noy [bell amusement buzzing] ${ }^{45}$; potekhimogutchiyemedniyezvuki[themightybrasssounds started flowing] ${ }^{37}$; zvookiskolokolapoleteli [the sounds from the bell started flying] ${ }^{38}$; zovkolokolovsrednevekoviy [a medieval call of the bells] $]^{46}$; govormedniy [brass talk] ${ }^{47}$; malinoviyzvonkolokolov [mellow chime of bells] $]^{48}$; nakrapyvayetkolokol'niydozhd' [bell rainis drizzling] ${ }^{40}$; medniysmekh [brass laughter], platchserebristiy [silvery crying $]^{42}$; torzhestvuyushchayamed' [triumphant brass] ${ }^{49}$; poneslis' udaryksinimnebesam [the strikes set off for the blue skies $]^{50}$, etc. The art of poetic toll of bells is related to the historic and to the battle field subject matters, to the subjective-personal and to the mankind-in-general symbolism: The sounds of bells have been attracting attention by their orthodox symbolism and by their philosophical and historical perception, they used to symbolize the approach of important historical events of universal importance, they announced important State developments, they reflected the essence of the way of life of that period, they used to bring people to the state of spirituality and equilibrium, they brought to life manifold emotions of joy, happiness, anguish. In the toll of bells the poets see both the symbol of Russian State and the reflection of the wide Russian soul.

An important role in the study of a poetic text belongs to a phenomenon of lexical synesthesia. Synesthesia, as one of the style creating elements of a poetic text represents "an active inclusion of synesthetic combinations in a poetic tissue, where the words, related to one sensory organ, are used to denominate the notions, related to another sensory organ" ${ }^{11}$. At the same time, synesthesia, orinter-modality, represents the "inter-sensor association" and serves as a source for creating unique metaphorical transfers, enabling the author to impart significance and expressiveness to the text, to improve the reader's perception of the work of art.

Those synesthetic constructions are interesting, in our opinion, where the perceptual modes of sound and colour are combined. Modern scientific achievements in the area of poetic text study enable us to maintain that not only the lexical, but also the phono-semantic level takes part in creating the poetic picture of the world. However, 
if from the view point of the phono-semantic aspect the investigations encompass different sides of the phonetic meaning, the sound-color associations, the means of sound pattern and sound symbolism (investigations by A. P. Zhuravlev, L. I. Soboleva, S. V. Bondar, V. N. Vinogradova, S. V. Piskunova, N. A. Melnikova, L. P. Prokofyeva), then the lexical approach implies studying the semantic component of the sound notation from the point of view of the lexical ambiguity and the metaphoric character intrinsic to the poetic image. Sound and color are coming forth from this position as the meaningful elements of the literary artist's perceptive picture of the world. Phonemic synesthesia becomes here a phenomenon of a new level, namely, a phenomenon of lexical synesthesia, evident both in the basis of the national language and in the language of a poetic text.

As demonstrated by the poetic context, a sound modus often prevails over the visual one in both direct and metaphoric planes, or, the sound and the color come to integration. In a poetic representation of the perceptive model of phonation the sound-color synesthesia covers three planes of manifestation. In the first place, the sound and the color get combined in one subject or event: zvuchashchiyeveseliyemluchi [the rays resounding with mirth], zvuchitsvetilodnya [the day-star is resounding], blagovestsolnechnykhluchey [the toll of the sun rays], rumyanoyegromkoyevosklitsaniye [ruddy loud exclamation], vzorovtikhost' [the silence of gazes], dyshat' rechamitikhimikaklunniysvet [to breathe with the speech as silent as moonlight] ${ }^{36}$; ustivzorovrazgovor [the talk of lips and gazes], tikhayasleza [a silent tear], shopotrazluki [whisper of parting] ${ }^{38}$. In the second place, sound-color images accompany each other when describing the objects or the facts of reality: den' shumel - ulitsablistala [the day was booming - the street was shining], zvutchitrozhok - svetnakholmakh(the [the horn resounds - the light is on the hills], znamenaveseloshumeli - nasolntseiskrilis' shtyki [the banners were rattling merrily - the bay onets were sparkling in the sun] ${ }^{36}$; zvukshagov - teninastenye [the footstep sounds - the shadows are on the wall], shumlesnoy - zelenirastitel'nayasyrost' [the murmur of forest - the vegetative dampness of greenery], vpetchitreshchitogon' - seryydymkovrom [the fire crackles in the oven - the grey smoke lies like a carpet]..$^{38}$ In the third place, sound - colour images come into mutually exclusive relations, when the presence of one modus assumes the absence of another and vice versa, for instance, ... glukhayapolnoch! Vsemolchit! Vdrug... iz-zatuchlunablesnula" [...dead midnight! Everything is silent! Suddenly... the moon blinked from behind the clouds], igasnettsvetizvooknemeyet" [and the colour goes out, and the sound gets dumb ...]; Tsvetpobleknul, zvookusnul [The colour faded, the sound got to sleep...] ${ }^{36}$. Of course, the synesthetic constructions serve as one of the means of verbal explication for the poet's esthetic message, testifying to the dominance of the perceptive picture of the world in general (est' vprirodezvuki, blagoukhaniya,tsvetaigolosa [in nature the reare sounds, fragrances and voices]).

Within the representation of the sound notation in a poetic text the author's specific means of the sound depiction are imbedded. Before being expressed in the lines of poetry, a sound often goes through the state of the poet's soul. Every thing that is represented in the sound, is, undoubtedly, born in the soul of the poet himself, and is then incarnated in the creation. The sounds bring about the emotional mood. Thus, in A. A. Akhmatova's poetry the precedent stage of the poet's creative reaction, the creative moment, reflecting the interpenetration of the real and the unreal, some times the infernal, is most definitely observed in the poem "Creativity", describing the process of creating the poetry lines by means of vivid sound images. The pre-creation phase is characterized by availability of loud, strong, strident sounds, dissipated in the space plane and gathering in circle gradually: here neumolkayushchiyboychasov [the strikes of the clock that never get silent], there, far awayraskatstikhayushchegogroma, zhaloby, stonygolosov [the burst of the abating thunder, complaints, groans of voices]. The culmination sound image which is born in this bezdneshopotovizvonov [abyss of whispers and chimes], becomes odin, vsyopobedivshiyzvook [one sound which has won over everything], to describe which the poetess uses other sound images. The tone value of sound perception is polyvalent: here appears a special "irreparable" silence, it is followed by a slight melodious clinging - the words, taking the image of "little signal bells of light rhymes", and further on comes a poem, the birth of which is associated with "the moan of white belfries" or with "the first morning strike".

As the poetic context sallow judging, the inner state of a poet is usually predetermined by the conditions of the surrounding world. In this regard, the poetic perception of sounds, is, as a rule, individualistic: the poet can perceive some sound impulses affecting him in some definite ways, but not comprehended by common people (cf. zvukikhaosa [sounds of chaos], nochnoygul [night booming]), or, on the contrary, the sounds, practically 
audible to everybody at the usual time of day and under usual conditions, affect the poet in some special way. Here the principle of building up the poetic soundmodel, indicated by T.M. Nikolayeva comes forth, the structural components of this model are subjectively specified: the assumed source of the perceived sound (the source of sound is unknown to the poet and he himself ponders on it; the source of sound is in the poet's soul, within himself, to be more precise; the sound is heard in the close vicinity of the poet; the sound comes from the distant sources); the state of the poet's soul before perceiving the sound (physical condition of insomnia; dark mood; general stressed anticipation; deliberate anticipation of the beginning of creative work); creative reaction of the poet, or the release of a poem (emotional reactions: of negative and positive character; reactions of creative character: the poet starts writing; the reaction is not directly transferred into a poetic text) ${ }^{52}$.

The role of sounds in the creative implementation of the mes and motives by the poet is obvious. In the poetic text the sound acquires quite definite connection to the subject-matter of being, of existence, of human life, becomes involved naturally in the emotional, social, philosophical context, helps in revealing love, nature, social subjects. For instance, the sound image expressing love, in the poems of F. I. Tyutchev is represented by a musical symbol of harp, and in the poetry of A. A. Fet there is the invariable image of lyre.

\section{Conclusion}

Reconstructing the literary artist's sound picture of the world exemplified by the representation of the key sound images in the language of the poetic text facilitates the following: 1. Enriching the understanding of the poetic linguistic picture of the world and the linguistic personality of the literary artist; 2 . Enhancing theoretical knowledge about the sound image, sound sphere, sound picture of the world, finding new definitions for theoretical ideas; 3. Revealing semantic features of the words notating the sounds and their explication exemplified by the basic principles of the poetic language semantic expression.

The prospective directions for further investigating the poetical sound picture of the world are as follows:

- Addressing the analysis of the sound notating words in the earlier poetical systems, particularly, in those of 12th-18th centuries, establishing the conceptual, lin- guistic and cultural, lexical and semantic, lexical and graphic features of the sound and its artistic functions.

- Investigating the sound in the phonemic and semantic aspects (sound imitation, sound pattern, sound repetition, sound arrangement of the text, semantics of the sound array).

- Observing the phenomena of transition from sound to silence, from sound to speech activity, investigating silence as linguistic and poetical phenomenon of speechlessness, as an attribute of death, of the absence of sound and of anticipating the sound.

- Determining the author's specific ways of representing the sound from the view point of traditional and poetic, popular and cultural, semiotic ideas, particularly, the interaction between the sound and the music, the sound and the elemental forces.

The principles of the analysis and the conclusions, obtained in the course of this study, can be used both theoretically, when further investigating the semantics of the poetical language and lexical-graphical interpretation of the poetic text, and practically, where they can be applied in the course of teaching linguistic disciplines, primarily, lexicology, semantics, and poetical semantics.

\section{Acknowledgment}

The author gratefully acknowledges financial support provided by Young Scientists Grant of the President of the Russian Federation (MK-4247.2014.6).

\section{References}

1. Bolotnova NS. Associativnoe pole hudozhestvennogo teksta kak otrazhenie poyeticheskoy kartiny miraavtora [Associative field of the artistic text as a reflection of the author's poetic picture of the world]. Bulletin of TGPU. 2004; 1(38):20-4. [in Russian].

2. Tyutchev AJ. Siluetyrusskikhpisateley [Tyutchev AY. The Outlines of Russian Writers]. Moscow: Respublika; 1994. p. 118-26. [in Russian].

3. Karaulov YuN. Russkyyazyk I yazykovaya lichnost [The Russian Language and the Language Personality]. Moscow: Nauka; 1987. [in Russian].

4. Karaulov YuN. Russkayayazykovayalichnostizadachieeizucheniya.Yazykilichnost [Russian Language Personality and the Issues of its Study. Language and Personality]. Moscow: Nauka; 1989. P. 3-10. [in Russian].

5. Tilman Ju D. Kulturnyekoncepty v yazykovoykartinemira (namaterialeliriki F.I. Tyutcheva) [Cultural concepts in the language picture of the world] [ $\mathrm{PhD}$ thesis in Philology]. Moscow; 1999. [in Russian]. 
6. Maslova ZhN. Poeticheskayakartinamiraieereprezentatsiya v yazyke [Poetic picture of the world and its representation in language] [Author's abstract of PhD Thesis in Philology]. Tambov; 2011. [in Russian].

7. Nurgazina AB. Kategoriyapoyeticheskoykartinymiraikoncept: ikhsootnoshenie. [Category of poetic picture of the world and the concept: Their correlation] Mir Nauki, Kultury, Obrazovaniya. 2013; 2(39):273-4. [in Russian].

8. Babenko LG. Ideograficheskoeopisanierusskoyleksikikaksposobvyyavleniyabazovyhkategorijikljuchevyhkonceptov. Russkijyazyk: istoricheskiesudbyisovremennost. III Mezhdunarodnyjkongressissledovatelejrusskogoyazyka: trudyimaterialy [Ideographic description of Russian lexis as the means of expressing the basis category and the key concepts. The Russian language. Historical destinies and modern time. Proceedings of $3^{\text {rd }}$ International Congress of the Russian Language Researchers]. Moscow: MAKS Press; 2007. [in Russian].

9. Makarova SA. Zvukovayakartinamira v poeticheskomtvorchestve A.A. Feta ( $\mathrm{k}$ voprosu o vzaimodeystviipoeziiimuzyki). Yazykikultura: Tretyamezhdunarodnayakonferenciyadokladov [Sound picture of the world in AA Fet's poetic works. Revisiting the issue of the interaction of poetry and music. Language and culture. $3^{\text {rd }}$ International Conference of Reports]. Kiev. 1994; 1:205-12. [in Russian].

10. Ozhegov SI. Slovarrusskogoyazyka [Russian Dictionary]. 70000 words. In: Shvedova NY, editor. Moscow; 1989. [in Russian].

11. SSRLYa. Slovarsovremennogorusskogoliteraturnogoyazyka [Dictionary of Modern Standard Russian Language]. In 17 volumes. Moscow-Leningrad; 1950-1965. [in Russian].

12. Krasovskaya NA. Khudozhestvenno-izobrazitelnyesvoystvazvukov $\mathrm{v}$ poeticheskoyrechi [Artistic and descriptive qualities of sounds in poetic speech]. Novgorod; 1998. [in Russian].

13. Vinogradova VN. Okkazionalizmyizvukopis. Tekst. Intertekst. Kultura. Sb. Dokladovmezhdunarodnoynauchnoykonferencii [Occasional constructions and sound pattern, text, intertext, culture. Book of reports of the international scientific conference]. Moscow: Azbukovnik. 2001; p. 53342. [in Russian].

14. Piskunova SV. Zvukovayasemantika v poeticheskomtekste [Sound semantics in the poetic text]. Bulletin of Tambov University. Gumanit. nauki. 2001; p. 21-4. [in Russian].

15. Melnikova NA. Semantikazvukovogostroya v poezii V. Khlebnikova: Zhivopisposredstvomzvuka [Semantics of sound array in the poetry of V Khlyebnikov: Painting by sound.] Gumanitarnoeznanie Omsk. 2002; 6:176-8. [in Russian].

16. Zhuravlev AP. Zvukismysl [Sound and Sense]. Moscow: Prosveshhenie; 1981. [in Russian].

17. Soboleva LI. Sinesteziyavospriyatiyaisistemnostleksiki [Synesthesia of perception and the systematic character of lexis]. Bulletin of Belorussian University. Series: Filologiya, Zhurnalistika, Pedagogika, Psihologiya. 1986; 1:44-9. [in Russian].

18. Prokofyeva LP. Natsionalnayasistematsveto-zvukovykh- sootvetstviyrusskogoyazyka. Yedinitsyyazykaiikhfunktsionirovanie [National system of color-sound correlations in the russian language. Units of language and their functioning] - Saratov. 1997; 3:57-63. [in Russian].

19. Bondar SV. Zvukovayastilistika: Aspektyfoneticheskogoznacheniya: avtoref [sound stylistics. aspects of phonetic meaning] [Author's abstract of PhD Thesis in Philology]. Moscow; 2001. [in Russian].

20. Kurashkina NA. Zvukooboznacheniyakakreprezentaciyazvukosfery v yazyke: namaterialeangliyskikh, frantsuzskikhirusskikhantropo-iornitofonov [Sound identifications as a representation of sounds in the language based on English, French and Russian anthropo-and ornitophones]. Ufa; 2007. [in Russian].

21. Yezhova EN. Lingvisticheskiesredstvazvukovogomira v poeticheskihtekstahO.Je. Mandel'shtama [Linguistic means of the sound world in poetic texts of Ye Mandelstam] Stavropol; 1999. [in Russian].

22. Atamanova NV. Semantikazvukooboznachenij v poezii F.I. Tyutcheva [Semantics of sound identifications in FY Tyutchev' poetry] [PhD Thesis in Philology]. Bryansk; 2006. [in Russian].

23. Gorbanevskaya GV. Semanticheskoe pole zvuchaniya v sovremennomrusskomyazyke [Semantic field of sound in modern Russian language] [Author's abstract of $\mathrm{PhD}$ Thesis in Philology]. Moscow; 1985. [in Russian].

24. Grigorenko OV. Leksicheskayasochetaemostraznokategorialnyhslov, oboznachajushhihzvuchanie [Lexical combinability of the sound identifying words of different character] [Author's abstract of PhD Thesis in Philology]. Voronezh; 1994. [in Russian].

25. Parkhomenko IV. Leksiko-semanticheskoe pole «Zvuk» iyegofunktsionirovanie $\mathrm{v}$ hudozhestvennomtekste: Na materialeliriki S.A. Yeseninai V.V. Mayakovskogo [Lexical and semantic field "sound" and its functioning in the literary text. Based on the material of lyrics by SA Yesenin and VV Mayakovski] [PhD Thesis in Philology]. Saratov; 2000. [in Russian].

26. Popova MV. Funkcional'no-semanticheskoe pole «Zvuk» v sovremennomrusskomyazyke [Functional and semantic field "Sound" in modern Russian language]. Rostov-na-Donu; 2002. [in Russian].

27. Vasilyev LM. Semantikarusskogoglagola: glagolyrechi, zvuchaniyaipovedeniya. Ucheb. Posobie [Semantics of Russian verb: Verbs of speech, sound and behavior. Textbook]. Ufa: Bashkirskiy State University Press; 1981. [in Russian].

28. Glushitch OD. Sushhestvitel'nye-zvukooboznacheniya v russkomyazykeiihfunkcionirovaniev hudozhestvennoyrechi [Nouns-sound identifications in the russian language] [Author's abstract of PhD Thesis in Philology]. Kiev; 1986. [in Russian].

29. Glushitch OD. Leksicheskayasochetaemostsushhestvitelnyh-zvukooboznachenij $\mathrm{v}$ russkomyazyke [Lexical combinability of the nouns-sound identifications in the Russian language]. Russkoeyazykoznanie. Kiev. 1989; 18:111-7. [in Russian]. 
30. Grigorenko OV. Glagolyzvuchaniya v russkomyazyke [Sound verbs in the Russian language]. Russkijyazyk v Shkole. 1999; 4:77-81. [in Russian].

31. Ivanova GM. Semantikazvukovogohudozhestvennogoobraza v poeticheskomtekste (namaterialestihotvoreniya U. H. Odena «Morskoypeyzazh»). Strukturaisemantikapredlozheniyaiteksta v germanskihyazykah [Semantics of the sound artistic image in the poetic text based on the material of UN Oden's Poem "Sea landscape"]. Leningrad. 1987; 19-25. [in Russian].

32. Komlev NG. Komponentysoderzhatelnoystrukturyslova: Predstavlenie, mirovozzrenie, chuvstvo, slovo, urovenznaniya, kulturnyykomponent, komponentpolya [Components of the word semantic structure. Idea, view of the world, feeling, word, level of knowledge, cultural component, field component]. Moscow: URSS; 2003. [in Russian].

33. Mansurova AV. Poetikazvukoobrazov v lirike M. Yu. Lermontova [Poetics of sound images in M Yu Lermontov's lyrics] [Author's abstract of $\mathrm{PhD}$ Thesis in Philology]. Tomsk; 2004. [in Russian].

34. Vinokur GO, Editor O yazykehudozhestvennoyliteratury: Uchebnoeposobie[On the language of fiction. Textbook]. Moscow: Vysshayashkola; 1991. [in Russian].

35. Bely A. «Poyeziyaslova»: Pushkin, Tyutchev, Baratynsky vzritelnomvospriyatiiprirody [Poetry of word. Pushkin. Tyutchev. Baratynsky in visual perception of nature] Moscow: Raduga. 2001; 480-5. [in Russian].

36. Tyutchev FI. Polnoesobraniestikhotvoreniy [Complete Edition of Verses]. Leningrad: Sovetskiypisatel; 1987. [in Russian].

37. Tolstoy AK. Polnoesobraniestikhotvoreniy v dvukhtomakh. [Complete collection of poems in two volumes] Vol 1. Stikhotvoreniyaipoemy [Verses and poems]. Leningrad: Sovetskiypisatel; 1984. [in Russian].

38. Fet AA. Vesenniydozhd. Stikhotvoreniya. Poemy [Spring rain, Verses, Poems.] Tula: Priokskoeknizhnoeizdatelstvo; 1983. [in Russian].

39. Stefanovskaya SV. Sposobysemiotizaciizvukovogomira (namaterialeyazykovs ideograficheskoysistemoypisma [Methods of semiotic construction in the sound word] [Author's abstract of PhD Thesis in Philology]. Irkutsk; 2012. [in Russian].
40. Tsvetaeva M. Stikhotvoreniya. Proza [Poems, Prose]. Moscow: Astrel Publishing House, Olymp, AST; 2000. [in Russian].

41. Blok AA. Izbrannoe [Selected]. Moscow: Olymp; 1999. [in Russian].

42. Akhmatova AA. Lirika [Lyrics].In: Chernyh V, Editor. Moscow: Khudozhestvennayaliterature; 1989. [in Russian].

43. Kozlova NN. Tsvetovayakartinamira v yazyke. UchenyezapiskiZabaykalskogogosudarstvennogouniversiteta [Color picture of the world in the language. Scholary Notes of Zabaykalskiy State University]. 2010; 3:82-7. [in Russian].

44. Golovanevskiy AL. PoeticheskiyslovarTyutcheva [Tyutchev's poetic vocabulary]. Bryansk: RIO BGU; 2009. [in Russian].

45. Baratynsky YeA. Lirika [Lyrics]. Minsk: Harvest; 1999. [in Russian].

46. Bunin IA. Stikhotvoreniya [Poems]. Moscow: Khudozhestvennayaliterature; 1985. [in Russian].

47. Balmont K. Stikhotvoreniya [Poems]. Moscow: Khudozhestvennayaliterature; 1999. [in Russian].

48. Gumilev N. Stikhotvoreniya. Serebryanyjvek. Poyeziya [Poems. Silver Age. Poetry]. Moscow: AST LCC, Olymp; 2001. [in Russian].

49. Bryusov VY. Lirika [Lyrics]. Minsk: Harvest; 1999. [in Russian].

50. Yesenin SA. Polnoesobraniesochineniy [Complete Works] in 7 volume. Moscow: Nauka; Golos, 1995-2002. Volume 1. Stikhotvoreniya. [Poems]. 1995; Available from: http://feb-web.ru/ feb/esenin/texts/es1/es1-128-.htm [in Russian].

51. Satretdinova AX. Sinesteziyakakosnovnoystileobrazuyushchiy element poeticheskogotekstaserebryanogoveka [Synesthesia as a basic style creating element of a poetic text of the silver age]. Izvestiya PGPU n.a. VGBelinskiy. Penza. 2012; 27:392-5. [in Russian].

52. Nikolaeva TM. Zvuki, kotoryeslyshattolkopoety. V Nikolaeva TM. Otzvuka k tekstu [The sounds only heard by poets. In: Nikolayeva TM From sound to Text]. Moscow: Yazykirusskoykultury; 2000. P. 449-62. [in Russian]. 